\title{
Physicochemical parameters of grape pomace subject to grape processing technology applied
}

\author{
Natalia Ageyeva*, Anastasia Tikhonova, Boris Burtsev, and Ekaterina Globa \\ North-Caucasian Federal Scientific Centre of Horticulture, Viticulture, Winemaking, Im. 40-letiya \\ Pobedy Str. 39, Krasnodar, 350901, Russian Federation
}

\begin{abstract}
This article presents experimental data on physicochemical parameters (humidity, density, bulk density, effective viscosity) of grape pomace of various white and red grape varieties, subject to the processing technology applied. It was established that pomace humidity varies across a wide range of values, subject to the grape variety, grape processing technology and pressure equipment. A study of Chardonnay pomace was used to note the influence of pressure equipment and processing technology upon pomace humidity. The values of density and bulk density had a strong invert correlation with the humidity index. With increase of humidity, the values of density and bulk density lowered both for white and red pomace. It was shown that the value of effective viscosity of pomace of white grape varieties varied from 8.8 (Chardonnay) to 12.8 (Gewürztraminer) Pa·s; that of red grape varieties varied from 13.2 (Pinot Noir) to 15.8 (Saperavi, fermented pomace) Pa·s. Such variation may have been related to the varietal peculiarities of grapes, pomace humidity, and concentrations of high-molecular compounds. The highest total of phenolic compounds was observed in extracts of fermented Saperavi pomace. The total of pectic substances in grape pomace varied from 5.5 to $7.2 \%$ of dry weight for the white grape varieties, and from 4.4 to $5.9 \%$ for the red grapes. As for the concentrations of pectic substances, Riesling, Pinot Blanc and Sauvignon Blanc pomace were distinguished among the white grapes, and fermented Cabernet Sauvignon pomace - among the red grapes.
\end{abstract}

\section{Introduction}

Grape pomace is the natural solid waste left over from winemaking activity (pressing grapes into wine). Its comprehensive processing is deemed necessary and useful from the viewpoint of environmental and health-improving activities (it contributes to reduction of environmental pollution), and as a highly efficient commercial activity. Grape pomace is a source for such valuable substances as polyphenols, organic acids, grape oil and pectin [18]. This fact proved that grape pomace can be used to produce biofertilizers [9-10]. The quantity of pomace varies widely depending upon the grapes' varietal peculiarities, and processing technologies applied. When continuous presses are used, the pomace output equals averagely to $13-15 \%$; in case of hydraulic presses, the output varies between 17

\footnotetext{
${ }^{*}$ Corresponding author: ageyeva@inbox.ru
} 
and 20\%; in case of screw presses, it reaches 21 to $23 \%$. The average composition of grape pomace is the following: skins - 37 to $39 \%$; pulp - 30 to $32 \%$; seeds - 28 to $30 \%$; stalks 1.1 to $1.5 \%$; grapevine leftovers -0.2 to $0.3 \%$ [11-12]. To reduce or eliminate the existing environmental contaminations arising due to the remaining secondary raw materials, it is necessary to substitute the existing outdated technologies with new ones which comply with modern requirements and facilitate the extraction and making the best use of all valuable components of grape pomace. Because of that, it is necessary to acquire new knowledge on physicochemical parameters and properties of grape pomace resulting from processing of various grape varieties with the use of new technological patterns and equipment.

Depending on the type of wine, the resulting pomace can be classified as follows: sweet pomace - the leftovers of production of white table wines, including base wine for sparkling wines; fermented pomace, resulting from pressing fermented grape must (with seeds and skins) according to the technology of red table wines production; and alcoholic pomace - the leftovers of liqueur wines production (Muscats and Kagors, whose production technology provides for grape must maceration and fermentation). To increase the grape juice output, many wineries have over the past 10 - 15 years been widely using enzyme products whose impact upon the chemical composition of grape pomace has not been explored so far.

Because of that, the objective of our work was to obtain new data on physicochemical properties and chemical composition of high-molecular compounds of grape pomace, depending upon the grape variety and processing technology applied.

\section{Study objects and methods}

As study objects, we used sweet (Chardonnay, Riesling, Sauvignon Blanc, Gewürztraminer, Pinot Noir), fermented (Cabernet Sauvignon, Merlot, Saperavi) and alcoholic (Gewürztraminer, Cabernet Sauvignon, Saperavi) pomace of classic Vitis vinifera cultivars, selected at wineries in Krasnodar region. The pomace was obtained during the manufacture of white and red table and liqueur wines. To separate pomace from juice or wine, membrane drum pneumatic presses made by various companies were applied. In certain grape processing technologies, enzyme products Trenolin Blanc and Trenolin Rouge (made by Erbsloeh Geisenheim AG, Germany) were applied in optimum dosages as recommended by the manufacturer. The humidity was calculated in percentage terms by weighing the sample prior to and after the drying. The drying was performed in the drying chamber at the temperature of $100^{\circ} \mathrm{C}$ to constant weight. All tests were repeated three times. The density was determined by weight method. The essence of bulk density determination method (the ratio between the weight and the occupied volume) lay in the determination of the weight of pomace that occupied a certain volume $\left(200 \mathrm{~cm}^{3}\right)$ at normalized compaction. For the purpose of studying high-molecular compounds, the reviewed variants of grape pomace were exposed to hot water $\left(90-95^{\circ} \mathrm{C}\right)$ extraction with the hydromodule of $1: 5$ for 6 hours. The mass concentration of the total of phenolic compounds was determined in the obtained extracts colourimetrically with the help of the Folin-Ciocâlteu reagent [13]; the content of pectin substances was determined by calcium-pectate formula [14].

Effective viscosity was determined with the help of a Rheotest-2 rotational viscosimeter [15]. The effective viscosity index $(\eta, \mathrm{Pa} \cdot \mathrm{s})$ was calculated by the following formula:

$\eta=\tau$ / D, where $\tau$ is shear stress, Pa; D is a corrected strain rate, c- $1(\mathrm{D}=0.6 \mathrm{c}-1)$;

$\tau=0,1 \mathrm{z} \alpha$, where $\mathrm{z}$ is the cylindrical measuring tool coefficient $(\mathrm{z}=273.1) ; \alpha$ is the value determined by an indicator dial. 
Pearson correlation coefficients for different variables were calculated in Microsoft Excel.

\section{Results and discussion}

Table 1 presents the study results for humidity, density and bulk density of grape pomace subject to the grape variety, processing technology applied and type of the press used. Knowledge of these figures is required for calculations of technological equipment and utilities for the purpose of design and construction of production departments or factories engaged in comprehensive processing of winemaking recyclables.

Table 1. Physicochemical parameters of grape pomace of various types

\begin{tabular}{|c|c|c|c|c|c|}
\hline Grape variety, type of pomace & Press made by & 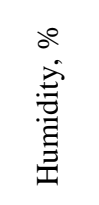 & 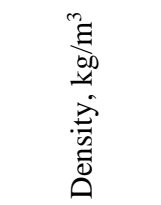 & 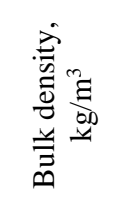 & 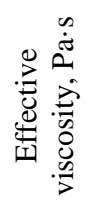 \\
\hline Chardonnay, sweet pomace & Diemme (Italy) & $50-52$ & $1120-1128$ & $360-380$ & 10.6 \\
\hline Chardon & Bucher Vaslin (France) & $65-67$ & $1112-1120$ & $280-310$ & 8.8 \\
\hline Chardonnay, sweet pomace & Enoventa (Italy) & $60-62$ & $1108-1110$ & $320-340$ & 9.4 \\
\hline Pinot Blanc, sweet pomace & Enoventa (Italy) & $60-62$ & $1118-1124$ & $300-320$ & 11.2 \\
\hline $\begin{array}{l}\text { Pinot Blanc, } \\
\text { sweet pomace + Trenolin Blanc }\end{array}$ & Enoventa (Italy) & $56-58$ & $1122-1126$ & $330-350$ & 9.2 \\
\hline Riesling, sweet pomace & Della Toffola (Italy) & $62-64$ & $1116-1120$ & $320-350$ & 8.6 \\
\hline $\begin{array}{l}\text { Riesling, } \\
\text { sweet pomace +Trenolin Blanc }\end{array}$ & Della Toffola (Italy) & $55-57$ & $1122-1125$ & $340-370$ & 8.2 \\
\hline Gewürztraminer sweet pomace & Enoventa (Italy) & $61-63$ & $1116-1120$ & $330-350$ & 12.4 \\
\hline $\begin{array}{l}\text { Gewürztraminer, } \\
\text { sweet pomace + Trenolin Blanc }\end{array}$ & Enoventa (Italy) & $56-58$ & $1121-1123$ & $360-380$ & 10.6 \\
\hline $\begin{array}{l}\text { Gewürztraminer alcoholic } \\
\text { pomace }\end{array}$ & Enoventa (Italy) & $53-54$ & $1123-1125$ & $370-400$ & 12.8 \\
\hline Sauvignon Blanc, sweet pomace & Enoventa (Italy) & $56-58$ & $1116-1118$ & $350-370$ & 10.3 \\
\hline Pinot Noir, sweet pomace & Bucher Vaslin (France) & $54-56$ & $1119-1122$ & $360-375$ & 13.2 \\
\hline Merlot, fermented pomace & Bucher Vaslin (France) & $46-48$ & $1121-1123$ & $375-395$ & 14.4 \\
\hline $\begin{array}{l}\text { Merlot, fermented pomace } \\
\text { +Trenolin Rouge }\end{array}$ & Bucher Vaslin (France) & $43-44$ & $1125-1127$ & $400-420$ & 12.8 \\
\hline Saperavi, fermented pomace & Bucher Vaslin (France) & $46-48$ & $1130-1132$ & $380-395$ & 15.8 \\
\hline Saperavi, alcoholic pomace & Bucher Vaslin (France) & $43-44$ & $1133-1135$ & $410-430$ & 15.2 \\
\hline $\begin{array}{l}\text { Saperavi, fermented pomace } \\
+ \text { Trenolin Rouge }\end{array}$ & Bucher Vaslin (France) & $44-46$ & $1135-1138$ & $445-460$ & 14.5 \\
\hline $\begin{array}{l}\text { Cabernet Sauvignon, fermented } \\
\text { pomace }\end{array}$ & Bucher Vaslin (France) & $45-47$ & $1126-1130$ & $400-415$ & 14.7 \\
\hline $\begin{array}{l}\text { Cabernet Sauvignon, alcoholic } \\
\text { pomace }\end{array}$ & Bucher Vaslin (France) & $43-44$ & $1128-1132$ & $430-445$ & 14.5 \\
\hline $\begin{array}{l}\text { Cabernet Sauvignon, fermented } \\
\text { pomace + Trenolin Rouge }\end{array}$ & Bucher Vaslin (France) & $43-45$ & $1130-1135$ & $445-460$ & 13.1 \\
\hline
\end{tabular}

The studies established that pomace humidity varies across a wide range of values, depending on the grape variety, processing technology applied and type of the press used:

- $\quad$ the humidity of sweet pomace of white grape varieties varied from $50-52$ (Chardonnay) to $62-64 \%$ (Riesling); the use of enzyme products encourages isolation of bigger amounts of grape juice, which is why the humidity of pomacedecreased regardless of the type of press used; 
- $\quad$ the humidity of fermented pomace of red grape varieties varied between 43 and $48 \%$; in this case, the use of enzyme products contributed to reduction of the humidity value;

the humidity of sweet alcoholic pomace of white Gewürztraminer grapes was lower than that of sweet pomace; most probably, it must have been related to the impact of ethyl alcohol upon the grape must (with skins and seeds): ethyl alcohol facilitated the diffusion of extractive components from the grape skins into the medium, entailing the output of grape juice (wine) and, consequently, decreasing the skins humidity value; similar trend was observed for alcoholic pomace of red grape varieties: the use of alcoholised must (with skins and seeds) reduced the pomace humidity.

By example of Chardonnay pomace, the impact of press equipment and processing technology upon the pomace humidity was shown: the humidity was the lowest when a Diemme press was used. The use of Enoventa and, especially Bucher Vaslin presses drove up the pomace humidity. This may have also been related to the type of wine the analysed grape variety was used for. Supposedly, at the pomace humidity of $65-67 \%$, less juice may have been chosen for the production of premium table wines.

The values of density and bulk density had a strong invert correlation with the humidity values: $r=(-0.84)$ and $r=(-0.93)$, respectively. With increase of humidity, the values of density and bulk density lowered both for white and red pomace. By comparing the experimental data, it may be noted that density and, especially, bulk density of fermented pomace significantly exceeded the similar figures for sweet pomace. The use of alcoholization and fermentation also led to the increase of the values of analysed parameters.

The values of density and bulk density of alcoholic, enzyme-treated and fermented pomace of Cabernet Sauvignon were higher than those of Merlot and Saperavi. This can be explained by a number of various reasons, especially by higher separation of wine in case of Cabernet Sauvignon, and high concentration of high-molecular compounds, first of all phenolic substances and polysaccharides, in Saperavi.

Effective viscosity, which in fact is a so-called 'seeming' viscosity of a composite heterogeneous system, is another important parameter of grape pomace. pomace processing is accompanied by the following concomitant processes: thermal - heating; mass-exchanging - mixing; and mechanical - rubbing, pipelining, and dosing. The performance of the abovementioned operations is accompanied by a greater or lesser extent of pomace structure destruction; because of that, significant changes were identified by rheological parameters responsible for the quality of the intermediate product, functioning of the equipment, and operating costs. Apart from that, rheological quality parameters, in particular the effective viscosity value, must be taken into account when deciding on the automation, intensification and optimization of grape pomace processing.

Grape pomace contains skins represented by coarsened parenchyma cells and cellulose; depending on the grape variety, it may have different looseness degrees. Pulp is represented by large parenchyma cells with intercellular spaces; depending on the variety, it may have different juiciness and either soft or hard consistency; it may be loose or tight, floury finegrained or coarse-grained by structure. It was availability of seeds that presented the biggest difficulty for the determination of effective viscosity, which is why prior to such determination all seeds had been removed manually.

The performed studies (Table 1) showed that the value of effective viscosity of white grape pomace varied between 8.8 (Chardonnay) and 12.8 (Gewürztraminer) Pa·s. Such difference may have been related to the varietal peculiarities of grapes, pomace humidity, and concentrations of high-molecular compounds. Even more significant variation of the value of effective viscosity was revealed in red pomace, in Pa·s: from 13.2 (Pinot Noir) to 15.8 (Saperavi, fermented pomace). In this case, the correlation between effective viscosity 
and humidity of pomace had a high invert correlation: $r=(-0.79)$. The main impact upon the value of effective viscosity was exerted by high-molecular compounds of pomace, some of which had gelling power. Must fermentation with enzyme products resulted in partial destruction of high-molecular compounds, this translated to a lower value of effective viscosity.

Table 2. Concentration of high-molecular compounds of grape pomace of various types

\begin{tabular}{|c|c|c|c|c|c|}
\hline \multirow{3}{*}{$\begin{array}{l}\text { Grape variety, type of } \\
\text { pomace }\end{array}$} & \multirow{3}{*}{ Press made by } & \multicolumn{3}{|c|}{ Concentration of extracts, $\mathrm{mg} / \mathrm{dm}^{3}$} & \multirow{3}{*}{ 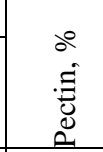 } \\
\hline & & \multicolumn{2}{|c|}{\begin{tabular}{|c|} 
polyphenols \\
\end{tabular}} & \multirow{2}{*}{$\begin{array}{l}\text { total poly- } \\
\text { saccharides }\end{array}$} & \\
\hline & & total & $\begin{array}{c}\text { incl. } \\
\text { anthocyanins }\end{array}$ & & \\
\hline Chardonnay, sweet pomace & Diemme (Italy) & $760-780$ & $138-145$ & $450-470$ & 6.3-6.5 \\
\hline Chardonnay, sweet pomace & $\begin{array}{l}\text { Bucher Vaslin } \\
\text { (France) }\end{array}$ & $610-650$ & $128-135$ & $400-425$ & $6.1-6.3$ \\
\hline Chardonnay, sweet pomace & Enoventa (Italy) & $640-670$ & $130-135$ & $410-425$ & $6.2-6.5$ \\
\hline Pinot Blanc, sweet pomace & Enoventa (Italy) & $730-750$ & $144-152$ & $415-430$ & $6.5-6.8$ \\
\hline $\begin{array}{l}\text { Pinot Blanc, sweet pomace } \\
+ \text { Trenolin Blanc }\end{array}$ & Enoventa (Italy) & $810-840$ & $131-136$ & $430-440$ & $5.2-5.6$ \\
\hline Riesling, sweet pomace & Della Toffola (Italy) & $740-770$ & $115-122$ & $400-415$ & $6.8-7.2$ \\
\hline $\begin{array}{l}\text { Riesling, sweet pomace + } \\
\text { Trenolin Blanc }\end{array}$ & Della Toffola (Italy) & $630-660$ & $100-107$ & 380-395 & $5.4-5.7$ \\
\hline $\begin{array}{l}\text { Gewürztraminer sweet } \\
\text { pomace }\end{array}$ & Enoventa (Italy) & $840-870$ & $224-230$ & $425-450$ & $6.3-6.6$ \\
\hline $\begin{array}{l}\text { Gewürztraminer, sweet } \\
\text { pomace + Trenolin Blanc }\end{array}$ & Enoventa (Italy) & $740-770$ & $196-206$ & $400-420$ & $5.5-5.7$ \\
\hline $\begin{array}{l}\text { Gewürztraminer, } \\
\text { alcoholic pomace }\end{array}$ & Enoventa (Italy) & $710-750$ & $198-212$ & $410-420$ & $5.7-6.0$ \\
\hline $\begin{array}{l}\text { Sauvignon Blanc, } \\
\text { sweet pomace }\end{array}$ & Enoventa (Italy) & $840-860$ & $156-164$ & $500-515$ & $6.6-6.9$ \\
\hline Pinot Noir, sweet pomace & $\begin{array}{l}\text { Bucher Vaslin } \\
\text { (France) }\end{array}$ & $1940-1970$ & $222-235$ & $480-500$ & $5.4-5.6$ \\
\hline Merlot, fermented pomace & $\begin{array}{l}\text { Bucher Vaslin } \\
\text { (France) }\end{array}$ & $2250-2300$ & $320-331$ & $520-540$ & $4.8-5.0$ \\
\hline $\begin{array}{l}\text { Merlot, fermented pomace } \\
+ \text { Trenolin Rouge }\end{array}$ & $\begin{array}{l}\text { Bucher Vaslin } \\
\text { (France) }\end{array}$ & $2010-2100$ & $245-253$ & $550-570$ & 4.4-4.6 \\
\hline $\begin{array}{l}\text { Saperavi, fermented } \\
\text { pomace }\end{array}$ & $\begin{array}{l}\text { Bucher Vaslin } \\
\text { (France) }\end{array}$ & $3680-3730$ & $480-485$ & $570-590$ & $5.2-5.5$ \\
\hline Saperavi, alcoholic pomace & \begin{tabular}{|l} 
Bucher Vaslin \\
(France)
\end{tabular} & $3560-3600$ & $450-465$ & $620-640$ & $5.0-5.2$ \\
\hline $\begin{array}{l}\text { Saperavi, fermented } \\
\text { pomace + Trenolin Rouge }\end{array}$ & $\begin{array}{l}\text { Bucher Vaslin } \\
\text { (France) }\end{array}$ & $3380-3410$ & $430-440$ & $580-600$ & $4.7-4.9$ \\
\hline $\begin{array}{l}\text { Cabernet Sauvignon, } \\
\text { fermented pomace }\end{array}$ & $\begin{array}{l}\text { Bucher Vaslin } \\
\text { (France) }\end{array}$ & $2620-2710$ & 380-395 & $470-490$ & $5.6-5.9$ \\
\hline $\begin{array}{l}\text { Cabernet Sauvignon, } \\
\text { alcoholic pomace }\end{array}$ & $\begin{array}{l}\text { Bucher Vaslin } \\
\text { (France) }\end{array}$ & $2560-2610$ & $360-380$ & $480-490$ & $5.3-5.5$ \\
\hline $\begin{array}{l}\text { Cabernet Sauvignon, } \\
\text { fermented pomace + } \\
\text { Trenolin Rouge }\end{array}$ & $\begin{array}{l}\text { Bucher Vaslin } \\
\text { (France) }\end{array}$ & $2430-2500$ & $340-360$ & $490-510$ & $4.8-5.0$ \\
\hline
\end{tabular}

Due to that, the concentration of high-molecular compounds - polyphenols and polysaccharides, including pectic substances - in the analysed pomace samples were studied. The obtained experimental data (Table 2) showed dependence of the concentrations of high-molecular compounds in grape pomace upon both grape variety and processing technology applied. 
Red grape pomace is known to be valuable raw material to produce polyphenol extracts, including those meant for production of medical preparations [16-19]. The highest quantities of the total of phenolic compounds were observed in the extracts of fermented Saperavi pomace. The use of alcoholization and, especially, enzyme products led to reduction of the quantity of polyphenols, including anthocyanins, in grape pomace. Phenolic compounds are known to be localized mainly in grape skins [20-21]. Consequently, the effect of ethanol and enzyme products upon red grape must that led to enrichment of wine with phenolic compounds, caused depletion of phenolic compounds in grape pomace.

A similar trend was observed for the total of polysaccharides, including pectic substances. The studies showed that the total content of pectic substances in white grape pomace varied between 5.5 and $7.2 \%$, and in red grape pomace - between 4.4 and $5.9 \%$ of dry weight. According to a contemporary view, these were rather high concentrations [15], which proves usefulness of grape pomace processing for pectin production. By collating the obtained experimental data, it may be noted that as for the concentrations of pectic substances, Riesling, Pinot Blanc and Sauvignon Blanc pomace were distinguished among the white grapes, and fermented Cabernet Sauvignon pomace - among the red grapes.

\section{Conclusion}

The above presented experimental data have proved difference in the values of physicochemical parameters of grape pomace subject to grape processing technology, which fact must be factored into the designing and constructing of technological equipment. Pomace of different grape varieties has been shown to contain high concentrations of pectin and phenolic substances and be a valuable raw material for secondary processing.

\section{Funding}

The research was carried out with the financial support of the Kuban Science Foundation in the framework of the scientific project № МФИ-20.1/22 “Disclosure of the mechanisms of transformation of biological objects of secondary raw materials of the wine industry for targeted management of the processes of its storage and processing”.

\section{References}

1. X. Zhao, S.-S. Zhang, X.-K. Zhang, F. He, C.-Q. Duan, FCh, 310, 125830 (2020)

2. R. Minjares-Fuentes, A. Femenia, M. C. Garau, J. A. Meza-Velázquez, S. Simal, C. Rosselló, CP, 106, 179-189 (2014)

3. Q. Jin, S. F. O’Keefe, A. C. Stewart, A. P. Neilson, Y. T. Kim, H. Huang, FBP, 127, 139-151 (2021)

4. N. S. Limareva, A. V. Mityanina, L. V. Donchenko, SNI, 4, 200-206 (2018)

5. A. V. Mityanina, Y. A. Andrzejchik, N. S. Limareva, EIQ manag, 1, $36-38$ (2018)

6. D. D. A. Kamer, T. Gumus, I. Palabiyik, A. S. Demirci, O. Oksuz, FH, 114, 106584 (2021)

7. A. N. Tikhonova, N. M. Ageeva, WW, 48, 52-53 (2019)

8. C. Beres, S. P. Freitas, R. L.de O. Godoy, D. C. R. Oliveira, R. Deliza, M. Iacomini, C. Mellinger-Silva, L. M. C. Cabral, JFF, 56, 276-285 (2019) 
9. M. Martínez Salgado, R. Ortega Blu, M. Janssens, P. Fincheira, CP, 216, 56-63 (2019)

10. A. S. Belkov, T. N. Vorob'eva, Fr. Grow. Viticult. of SR, 63, 171-180 (2020)

11. R. Sirohi, A.Tarafdar, S. Singh, T. Negi, V. K. Gaur, E. Gnansounou, B. Bharathiraja, BT, 314, 123771 (2020)

12. C. Beres, G. N. S.Costa, I. Cabezudo, N. K. da Silva-Jame, A. S. C. Teles, A. P. G.Cruz, C. Mellinger-Silva, R. V. Tonon, L. M. C. Cabral, S. P.Freitas, WM, 68, 581594 (2017)

13. V. G. Gerzhikova Methods of technochemical control in winemaking (2002)

14. N. S. Limareva, A. V. Mityanina, L. V. Donchenko, Mod SI, 4 , 200-206 (2018)

15. L. A. Zabodalova, M. S. Belozerova, Engineering rheology, 41 (2016)

16. A. M. Brezoiu, C. Matei, M. Deaconu, A. M. Stanciuc, A. Trifan, A. GasparPintiliescu, D. Berger, FCT, 133, (2019)

17. E. Torre, G. Iviglia, C. Cassinelli, M. Morra, N. Russo, 45, 1721-1734 (2020)

18. F. Lu, F. Liu, Q. Zhou, X. Hu, Y. Zhang, FSN, 7, 2897-2906 (2019)

19. S. S. Balea, A. E. Pârvu, M. Pârvu, L. Vlase, C. A. Dehelean, T. I. Pop, FPh, 11 (2020).

20. V. P. Klimenko, D. O. Turaev, E. A. Lushchay, V. V. Likhovskoi, MWW, 3, 190-203 (2019)

21. A. Seker, B. Arslan, S. Chen, M, 24 (2019) 